Essay

\title{
Christianity and Darwinism: The Journey Is More Important Than the Destination
}

\author{
Michael Ruse
}

check for

updates

Citation: Ruse, Michael. 2021. Christianity and Darwinism: The Journey Is More Important Than the Destination. Religions 12: 124. https://doi.org/10.3390/rel12020124

Academic Editor: John A. Bloom

Received: 19 January 2021

Accepted: 12 February 2021

Published: 16 February 2021

Publisher's Note: MDPI stays neutral with regard to jurisdictional claims in published maps and institutional affiliations.

Copyright: (C) 2021 by the author. Licensee MDPI, Basel, Switzerland. This article is an open access article distributed under the terms and conditions of the Creative Commons Attribution (CC BY) license (https:// creativecommons.org/licenses/by/ $4.0 /)$.
Department of Philosophy, Florida State University, Tallahassee, FL 32306, USA; mruse@fsu.edu

\begin{abstract}
Does God exist? If he does, what is the evidence for this? Can one arrive at God through reason (natural theology), or is it faith or nothing (revealed theology)? I write of my lifetime of wrestling with this question. Raised a Quaker, I lost my faith at the age of 20. As an academic, I became an expert on Charles Darwin and his theory of evolution through natural selection. How can I make sense of-and how can I reconcile-these two hugely important things in my life? At the age of 80, I find myself a long-standing agnostic. This is not, as Francis Collins claims, a "cop out." Showing my debt to my Quaker heritage, I am theologically apophatic. I can say only what I do not know. I find this quite-out-of-character modesty hugely exciting. It gives my life great meaning.
\end{abstract}

Keywords: Darwinism; creation science; mechanism; organicism; root metaphor

\section{Setting Out}

I just turned 80 years old and retired after 55 years of teaching philosophy. Looking back, I see that mine has been a very fulfilled life, in main part because I have been on a journey of self-discovery. Have I now reached my destination? I am not sure I have and, to be honest, I would be a little worried had I done so, for then I would be dead, literally and metaphorically. Truly, the journey is more important than the destination. In this somewhat autobiographical essay, I want to share with you my journey, particularly as I have wrestled with the relationship between religion and science, and even more particularly as I have wrestled with the relationship between Christianity and Darwinism. Why have I found this so very exciting and why, in so many ways, do I not want it to stop?

I was born in England shortly after the beginning of the Second World War, a day or two after the fall of France. My father was a conscientious objector, I think mainly on Oedipal grounds, for his professional-soldier father had abandoned him to go to fight in the First World War and never returned home. Be this as it may, he worked with Italian prisoners of war, and this brought him into contact with members of the (pacifist) Religious Society of Friends, Quakers. After the war, he and my mother joined the Society. My sister and I were brought up as Quakers, and this was always a very vital part of our homelife. In my teens, I even went away for 6 years to a Quaker boarding school. Quakers do not have dogmas-articles of faith you must sign to stay in good membership-but they do have very strong beliefs. They are not only committed to the existence of God but to Jesus, as His incarnate son, who died for us on the Cross. Particularly important was the belief in the ongoing activity of the Holy Spirit, the Inner Light, or what we used to call "that of God in every person." Children within the Society were not forced to believe anything, but they were taught and supported by more senior and experienced Friends. Many members of the Society were educators, so that all happened naturally. The result is that I spent many-incredibly happy and fulfilling-hours of my young life, particularly from about ages 8 to 13 (when I went away to school), learning and arguing and agreeing and disagreeing, feeling secure that I was entitled to my opinions, and that, although others may disagree, I was not going to be bullied into changing my mind.

When I went off to university, at around the age of 20, two things happened. One was that I encountered philosophy as a discipline. My first class was on Descartes' Meditations, 
and I knew within 5 min that that was what I was going to do for the rest of my life. You mean that grownups worry about what has intrigued me from early childhoodam I awake or asleep, and do my parents still exist when they have left the room and I can no longer see or hear them? I should say, in the 60 years following, I may in good Cartesian fashion be able to doubt many things, but I have never doubted my commitment to philosophy. My Quaker childhood of ongoing inquiry was all-informative here. I should say also that, 5 years later, when I first walked into a classroom as teacher, within $5 \mathrm{~min}$ I knew that that was what I was going to do for the rest of my life. I have never doubted this conviction, either. I was teaching at a newly founded university in rural Ontario, and many of my students were the children of people who had left war-torn Europe in the 1940s and 1950s to build a new life in Canada. The parents would work long hours in boring jobs, so that their children would get a start in life that they never had. What a privilege to be part of this. My Quaker childhood counted here too!

The second thing that happened to me about the time of going to university is that I lost my faith. I did not have a Saul-on-the-road-to-Damascus experience in reverse. Like the baker in Lewis Carroll's nonsense poem, when my faith met the Snark, it turned out to be a Boojum, and "softly and silently vanished away." I just realized that I did not believe in God and that was it. You may feel I should link my loss of faith with my coming to philosophy, but I truly do not think that was so. After all, I had been doing philosophy all my life! I suppose that back then, you might have called me an "atheist," but even then, I think that would have been a little strong. Richard Dawkins hates Christianity. That was never me. If you grow up as a Quaker, you may have a distrust of organized religion. To this day I ask what the elaborate ceremonies of the Vatican have to do with Jesus of Nazareth, and I much doubt that he was a fervent defender of the Second Amendmentbut you never hate Christianity or Christians, taken individually. I pride myself on my ecumenical nature in this respect. I doubt many people can say that they contributed to the Festschriften of the Head Intelligent Designer, Phillip Johnson, and of the Head New Atheist, Richard Dawkins in the same year!

I was a nonbeliever - call me an "agnostic" rather than an "atheist" - but even then, I did not know quite what that meant. It was in this frame of mind that in my late 20s, working on my doctoral thesis (what Americans call a dissertation), that I first encountered Charles Darwin and his theory of evolution through natural selection as given in his Origin of Species (1859). Again, I cannot pretend there was much direction to any of this. I knew of evolution and suppose I accepted it, but when I was a schoolboy, we all wanted to be rocket scientists, so we studied physics and chemistry and never biology. Those of my readers who have done, or are doing, a doctoral degree, know that, for your choice of thesis topic, you need something on which there is little literature and that is not very good. Stay away from Aristotle on ethics and Hume on causation! Biology was a muchunderstudied philosophical topic, so I wrote on it! It just so happened this was the late 1960s, when Thomas Kuhn was all the rage, and, while few accepted his rather radical idealism-ontologically the world changes when conceptual frameworks (paradigms) change-we all bought into the insistence that to do good philosophy of science you must know the history of science. This led me to Darwin, to my first sabbatical spent in the manuscripts room of the University Library in Cambridge studying Darwin's notebooks, and to writing a book The Darwinian Revolution: Science Red in Tooth and Claw (Ruse 1979).

\section{Creation Science}

I think, to be honest, in my 30s, what with starting and raising a family and building a career, some of the more existential questions, as one might say, got rather shelved. I worked on Darwin, but more from a history-of-ideas sort of perspective-showing that Kuhn was right about the psychological shock of paradigm change but wrong in arguing that there was no intellectual continuity between paradigms. The influence of Paley's Natural Theology on the argument of the Origin, for instance. But things were about to change. By the end of the 1970s, the Creationists—or "Creation Scientists" as they styled themselves—were on a 
roll, pushing their biblical literalism as an alternative to Darwinian evolutionary theory. In 1981, they succeeded in getting a bill passed in the State of Arkansas, mandating that, if evolution be taught in state-supported public schools, Creation Science must be given "balanced treatment" in classes. At once, the American Civil Liberties Association (ACLU) brought suit, arguing that the law was in conflict with the First Amendment separation of church and state. A court case ensued. Among the expert witnesses for the ACLU were Langdon Gilkey, at that time the most eminent Protestant theologian in America; Steven Jay Gould, the paleontologist and popular science writer; and Michael Ruse. I was there, despite being a non-American, at an almost unknown Canadian university, because I had a full grasp of the history of the Darwinism/Christianity conflict and also because I was ideal witness material. I had 15 years of teaching undergraduates and knew that, in a public forum, the last thing one needs is a learned professional lecture. A good joke can be worth 10 detailed arguments. We won. The judge ruled decisively that Creation Science is religion and hence cannot be taught in state-supported public schools. My testimony (says he, immodestly but truly) was the crux of the ruling. Having looked at more sociological characterizations of science, the judge said flatly:

More precisely, the essential characteristics of science are:

(1) It is guided by natural law.

(2) It has to be explanatory by reference to natural law.

(3) It is testable against the empirical world.

(4) Its conclusions are tentative, i.e., are not necessarily the final word.

(5) It is falsifiable (Ruse and other science witnesses).

Creation Science ... fails to meet these essential characteristics (Ruse 1988)

\section{Engaging}

Very satisfying. But, in a way, just a beginning. It was at this point I began to grow up. What I mean is that I started to see that the religion/science issue is not just an academic exercise, but much more meaningful, especially more meaningful for one who had a background like mine. In this—and it is not too pretentious to say - spiritual growth, hugely important was a group of liberal Christians-mainly Unitarian-Universalist (UU) and United Church of Christ (UCC), but with some others, including liberal Lutherans attached to the Lutheran School of Theology at Chicago (LSTC) — who asked me to join them for their annual conference, held each summer on Star Island, one of half a dozen or so islands-the Isles of Shoals - off the coast of New Hampshire. I have long been attending meetings, first alone and then with family, of this group as unpretentious individually as their collective title- "The Institute for Religion in an Age of Science" (IRAS) - is embarrassingly selfimportant. Being with these people, and especially the magical/mystical beauty of the surroundings-rocky outgrowth surrounded by the always vital Atlantic-has helped me immeasurably in my journey from my childhood to where I am now.

Most important and immediately, I started to think seriously about the relationship between Darwinian theory and Christianity. I was not on my way back to Christianity-I have not gone that way to this day-but, as I have said, if you grew up as a Quaker, you cannot hate Christianity, nor can you ignore its often good effects. Friends from the beginning were leaders in the campaign against slavery. Not that Quakers had a lien on doing good, guided by their faith. I am not sure anything can counter the evil of the Nazis, but if anyone can it is Sophie Scholl, of the White Rose group in Munich in 1943, who died on the guillotine for her Christian-driven opposition to the Third Reich. With the help of my Christian friends, I became increasingly aware that the simple opposition of Christianity with evolution is horrendously incomplete. Creationists and atheists both push this. Leading Creation Scientist Henry M. Morris (2020) stated flatly, "Evolution on any significant scale does not occur at present, and never happened in the past, and could never happen at all." In parallel, the leading Darwinian evolutionist, Chicago biologist Jerry Coyne (2012), wrote: 
Evolution is the greatest killer of belief that has ever happened on this planet because it showed that some of the best evidence for God, which was the design of animals and plants that so wonderfully matched their environment could be the result of this naturalistic, blind materialistic process of natural selection.

Anglican minister and future Templeton Prize winner, Arthur Peacocke, whom I met on Star Island, used to counter these extreme positions by quoting the late-19th-century, High Anglican theologian Aubrey Moore:

Darwinism appeared, and, under the guise of a foe, did the work of a friend. It has conferred upon philosophy and religion an inestimable benefit, by showing us that we must choose between two alternatives. Either God is everywhere present in nature, or He is nowhere. He cannot be here, and not there. He cannot delegate his power to demigods called "second causes." In nature everything must be His work or nothing. We must frankly return to the Christian view of direct Divine agency, the immanence of Divine power from end to end, the belief in a God in Whom not only we, but all things have their being, or we must banish him altogether. (Moore 1890, pp. 99-100)

I will not say I was ever an out-and-out Hegelian, thinking you have a thesis and then an antithesis, and from these emerges a synthesis, but he had a point. I felt that, at the very least, we had to show that the discussion was not going off at half-cock, seeing antagonism and opposition which simply did not exist. I am not much given to appeals to authority, but when a leading scientist and avowed evolutionist, Francis Collins, Director of the National Institutes of Health, can proudly attest to his deep Christian faith, then I know something is wrong. This led me to write a book which, to say the least, surprised some of my friends. In my Can a Darwinian be a Christian? The Relationship between Science and Religion (Ruse 2001), I concluded that a Darwinian can be a Christian. I warned that it was not easy. In full-headmaster, portentous mode, I concluded stenoriously, "But whoever said the important things in life are easy?" Basically, I ran through the standard issues-literal interpretations, miracles, evil, and so forth-showing how Christianity could be reconciled with Darwinian thinking. I am pleased to say that, overall, my position was received favorably. The book sold really well! But, even back then, I was not easy. I felt that I was really working on the problems of others. To say that the problem of evil is well rehearsed is a bit like saying that adolescent schoolboys want only one thing. I do not mean that the book was just a formal exercise. Looking back, I see now, almost malgré moi, that I was being pushed a bit. Quakers are not in the Augustinian tradition of thinking the death on the Cross is a blood sacrifice to counter human sinfulness because of the sin of Adam. They are much more in the Incarnationalist tradition of Irenaeus of Lyons, regarding the death as an example of perfect love to be emulated by us humans. In writing my book, I realized that it was not just theology that made Augustine unacceptable. Now for me, evolution also countered him. It simply is not true that there was an original Adam and Eve. The human species never dropped beneath 10,000 people, and the mums and dads of those Adam and Eves were as bad (and as good) as all humans. That apple is getting a bum rap for what existed already. What I now realize is that this was a significant way in which my commitment to evolution was starting to shape my approach to the Darwinism-Christianity issue. I was/am an agnostic about the overall question of my belief in God, but not entirely blank-slate agnostic. I was/am atheistic about Augustinian Christianity, putting me on the outs with Lutherans, Calvinists, and others-including the Anglicans, although I am not sure how many of them have ever read the "Thirty-Nine Articles."

A start, but only a start. The question is: What I could bring to the evolution/Christianity debate that would help us to go further than most of us had gone before? For me, the path I saw and followed took me back to history. Let me explain.

\section{Rival Root Metaphors}

Return to Thomas Kuhn's The Structure of Scientific Revolutions (Kuhn 1962). Kuhn argued that the traditional view of science as telling it like it is-Dragnet-style: "Just the 
facts, ma'am, just the facts" - is quite wrong. Scientists see the world through conceptual frameworks, "paradigms," that color perception and guide research. Despite criticism of his idealistic conclusion that change of paradigms was ontological as well as conceptual, I agreed-and continue to agree - that conceptual frameworks, paradigms, guide our thinking. Later, Kuhn (1993) came to identify paradigms with metaphors, another move that I find deeply enlightening. Kuhn argued that change of paradigms is temporal, with one paradigm replacing another. I am more inclined to interpret paradigms in a broader sense, as ongoing conceptual frameworks, or metaphors. Some metaphors-root metaphors-embrace everything. In the words of linguist Stephen C. Pepper (1942), "A man desiring to understand the world looks about for a clue to its comprehension. He pitches upon some area of common sense fact and tries to understand other areas in terms of this one. The original area becomes his basic analogy or root metaphor." World pictures. Paradigms.

This is reasonably noncontentious. As is the claim that the history of Western science has seen the domination of two such root metaphors - the world as an organism and the world as a machine: "Organicism" and "mechanism" (Ruse 2021a). From the Greeks down to the Scientific Revolution, the world was seen through the lens of an organism. This was the ordering principle of understanding. Plato set the scene in his Timaeus, arguing that the Demiurge, identified with the Form of the Good, had designed the universe as an organism, and this is why we can and must think of it in terms of ends (Cooper 1997). The point or the purpose of the eye is to see and so, analogously, everything, organic and inorganic, must have an end or purpose. The world in a very real sense is living-Gaia-like, in today's terms. Aristotle, a biologist before he was a philosopher, dropped the external designer in favor of a more internally focused, nonmaterial force, but it still meant that for true understanding one had to think organically, in terms of ends, or what Aristotle called "final causes." One had "efficient causes" that explain how things come to be, and "final causes" that explain why things come to be (Barnes 1984).

This metaphor was readily given a Christian interpretation. The world itself was not and could not be God. It is His creation. But as we humans show fully, God creates organisms, so why not the world as a whole? But, by the late Middle Ages, the organic metaphor was under threat. The world was changing. People were starting to use machines to aid them in daily life-clocks, notably, for telling time. This did not always sit easily within the organic metaphor, the world as an organism. In the modern age, rubbing in the point using the replacing metaphor, the organic metaphor was running out of steam. A new root metaphor was called for: The world as a machine. That is the real import of the Scientific Revolution, a change of metaphors, from the organism to the machine. Now, the world was conceived mechanically.

At all times there used to be a strong tendency among physicists, particularly in England, to form as concrete a picture as possible of the physical reality behind the phenomena, the not directly perceptible cause of that which can be perceived by the senses; they were always looking for hidden mechanisms, and in so doing supposed, without being concerned about this assumption, that these would be essentially the same kind as the simple instruments which men had used from time immemorial to relieve their work, ... (Dijksterhuis 1961, p. 497)

\section{Mechanism Triumphant?}

To say that the machine metaphor proved incredibly fertile needs no argument. It has led to the triumphant march of four centuries of great science. However, from the first, there was the problem of organisms. Final-cause thinking was not allowed under the machine metaphor, and yet it seemed to be so obviously the case that, when it comes to organisms, final-cause thinking is essential. The hand and the eye do not just exist, nor are they an explanation in terms of efficient causes sufficient. The hand is for grasping - the final cause of the hand is grasping; and the eye is for seeing - the final cause of the eye is seeing. If you do not speak to these problems, then your science is inadequate. Incomplete. What is one 
to do? Late-17th-century chemist and philosopher, Robert Boyle, distinguished between acknowledging the use of final causes qua science and the inference qua theology from final causes to a designing god. First, "In the bodies of animals it is oftentimes allowable for a naturalist, from the manifest and apposite uses of the parts, to collect some of the particular ends, to which nature destinated them. And in some cases we may, from the known natures, as well as from the structure, of the parts, ground probable conjectures (both affirmative and negative) about the particular offices of the parts" (Boyle 1688, p. 18). Then, the science finished, one can switch to theology: "It is rational, from the manifest fitness of some things to cosmical or animal ends or uses, to infer, that they were framed or ordained in reference thereunto by an intelligent and designing agent" (Boyle 1688, p. 19). From a study in the realm of science, of what Boyle would call "contrivance," to an inference about design —or rather Design — in the realm of theology.

Organisms were booted out of science into the realm of religion. A solution, but hardly a satisfactory solution, for all that, over the next century or more, some good biological science was done thanks to this uneasy compromise. Naturalistic mechanistic thinking in the physical sciences. Religion-entwined organismic thinking in the biological sciences. People went on worrying. Kant, a hardline mechanist, appreciated the need of final-cause thinking, but argued that it is merely a guide, a heuristic. That did not stop Kant from being rather judgmental (in a negative way) about biology. You want to make the life sciences equal to the physical sciences? No way! It is just plain silly: "To hope that there may yet arise a Newton who could make comprehensible even the generation of a blade of grass according to natural laws that no intention has ordered; rather, we must absolutely deny this insight to human beings" (Kant [1790] 1928, p. 37).

\section{Romanticism}

It is hardly surprising that there was a reaction to all of this. In Germany, in particular, at the end of the eighteenth beginning of the 19th century, there was the rise of a movementRomanticism, often in science called Naturphilosophie - that urged a return to the organic metaphor, organicism (Richards 2003). Philosopher Friedrich Schelling argued that we must see everything, in some sense, the product of our own mind: "Nature should be visible mind, mind invisible nature. Here, therefore, is the problem that must be solved: in the absolute identity of mind in us and nature outside of us, how is external nature possible? This goal of our further research is thus the idea of nature" (Schelling [1797] 1988, p. 137). The mind is organic-it is the organism-hence nature is organic.

Note one important implication of organicism. Organisms grow, from acorn to oak tree, from caterpillar to butterfly, from fertilized ovum to philosopher. For the organicist, evolution - whether physical or ideal—is part of the package deal. And, in some sense, this implies progress. And one and all assumed the apotheosis of the progressive process is humankind. This is shown very clearly in the thinking of the mid-19th-century contemporary of Charles Darwin, Herbert Spencer. Like Darwin, Spencer was an evolutionist-a convert 10 years after Darwin, he nevertheless went public 10 years before Darwin. Spencer does not offer much evidence for his position, but it is noteworthy that the organic analogy is at the center of his thinking: "Surely if a single cell may, when subjected to certain influences, become a man in the space of twenty years; there is nothing absurd in the hypothesis that under certain other influences, a cell may, in the course of millions of years, give origin to the human race" (Spencer [1852] 1868, p. 381). 
The early-20th-century vitalist, Henri Bergson, was another who thought in this mode. Bergson (1907) was the champion of the neo-Aristotelian life force, the élan vital. He is better known as a "vitalist" rather than the more comprehensive "organicist," but the philosophy is the same: "Not only does consciousness appear as the motive principle of evolution, but also, among conscious beings themselves, man comes to occupy a privileged place. Between him and the animals the difference is no longer one of degree, but of kind" (Bergson 1911, p. 34). We can put matters more strongly: "In the last analysis, man might be considered the reason for the existence of the entire organization of life on our planet" (Bergson 1911, p. 35).

Also in this mode was Englishman Alfred North Whitehead, who moved to America and became an influential metaphysician. In Science and the Modern World (Whitehead 1926), he affirmed: "Nature exhibits itself as exemplifying a philosophy of the evolution of organisms subject to determinate conditions" (p. 115). Unsurprisingly, we learn that "The whole point of the modern doctrine is the evolution of the complex organisms from antecedent states of less complex organisms," "the organism is a unit of emergent value," and so on and so forth (p. 110). No surprise that the whole book leads up to a final chapter on humans and what is needed to keep our progress active. Romanticism, through and through.

As stressed, the organicists were and are ardent evolutionists, and, as also stressed, this brings with it the idea of progress, specifically to the highest organic form, Homo sapiens. Look at the tree of life of late-19th-century German biologist, Ernst Haeckel (1896). (Figure 1).

If humans are the ultimate final cause, what then, you might ask, is the efficient cause? What fuels this whole process? In some sense, one knows that it must be something internal rather than external. The individual organism, while growing, needs food and drink, but the change comes from within. It is not external forces making the acorn turn into an oak rather than an elm. So, it has to be for the evolution of groups. Exactly what internal forces might be involved tends to bring on a certain fuzziness. Today, there is a lot of solemn talk about embryology and development. Molecular biologists are now heavily involved in tackling the changes to evolutionary development-"evo-devo" for short-and it is thought that when all is spelt out, the mysteries of efficient causes will be dissolved. 


\section{PEDIGREE OF MAN.}
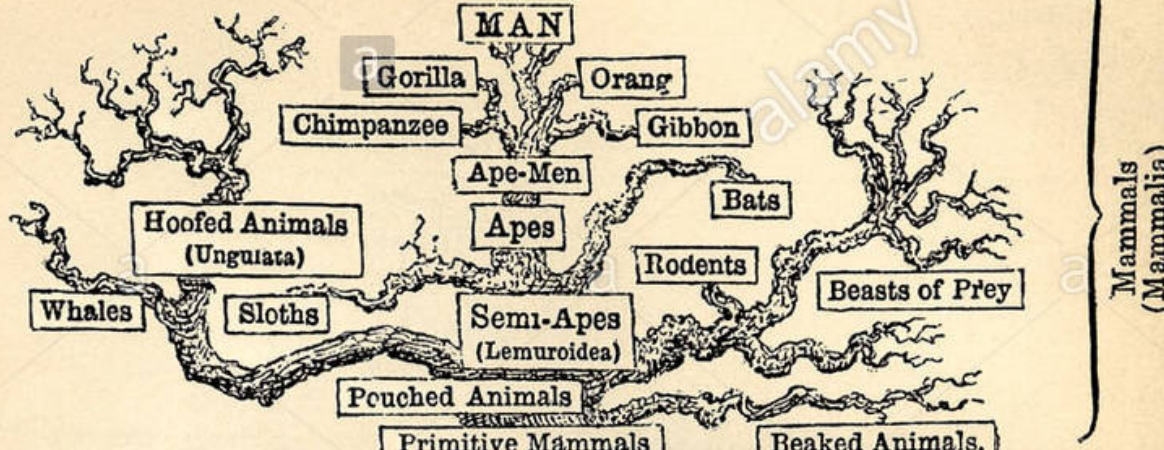

Primitive Mammals Beaked Animals. (Promammalia)
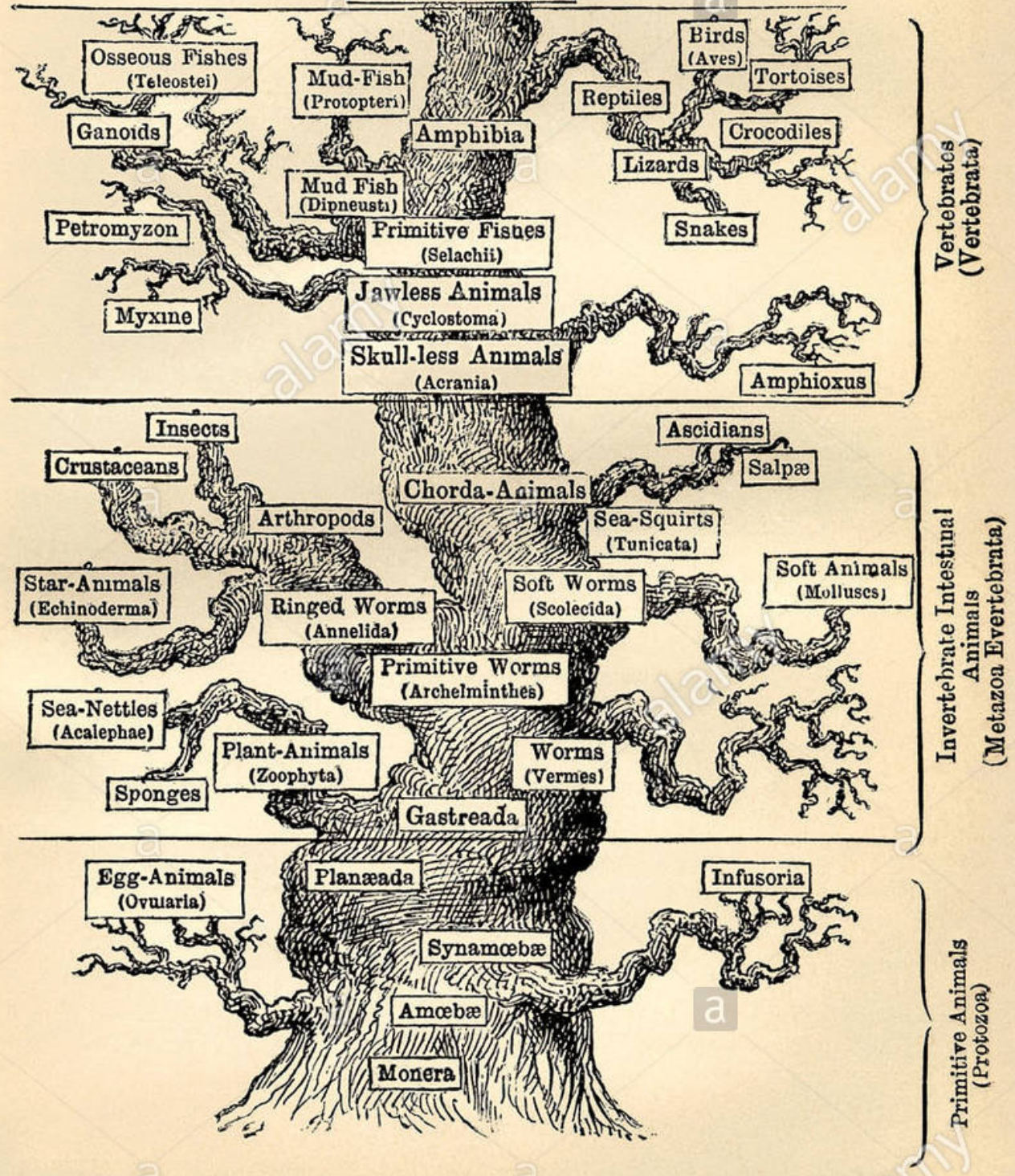

\section{a alamy stock photo}

Figure 1. Image is available as public domain at: https://commons.wikimedia.org/wiki/File: Tree_of_life_by_Haeckel.jpg accessed on 15 February 2021. 


\section{Charles Darwin}

As evolution came readily to the organism-metaphor world, so evolution came readily to the machine-metaphor world too. This was hardly forced. Organisms had to come from somewhere, and a Genesis account is not science. There is every reason to think that organisms developed naturally, by perfectly conventional efficient causes. The question is what causes, and how did this then play out for the final-cause dilemma? It was Charles Darwin with his theory of evolution through natural selection who cut the Gordian knot. First, he accepted, what 18th-century Anglican clergyman Thomas Robert Malthus had argued, that population numbers tend to rise much more quickly than available food and space. There will be a consequent "struggle for existence." Although he did not know why exactly, a near decade-long study of barnacles had convinced Darwin that there is lots of variation in all natural populations and, seemingly, an inexhaustible supply of new variation (Darwin 1851a, 1851b, 1854a, 1854b). This led Darwin to infer that there is a natural equivalent to the selective breeding methods used by farmers and pigeon fanciers and the like.

Can it ... be thought improbable, seeing that variations useful to man have undoubtedly occurred, that other variations useful in some way to each being in the great and complex battle of life, should sometimes occur in the course of thousands of generations? If such do occur, can we doubt (remembering that many more individuals are born than can possibly survive) that individuals having any advantage, however slight, over others, would have the best chance of surviving and of procreating their kind? On the other hand, we may feel sure that any variation in the least degree injurious would be rigidly destroyed. This preservation of favourable variations and the rejection of injurious variations, I call Natural Selection. (Darwin 1859, pp. 80-81)

Now, the all-important thing about natural selection is that it does not just lead to change but to change of a particular type. It explains "adaptations"- the hand and the eye- the very things for which Plato invoked a designer, Aristotle, and forces that are not material-in Bergsonian terms, élans vitaux. Variations that help their possessor are kept, and variations that do not help are eliminated. Added up, the favorable variations make for adaptations.

We start to see that Jerry Coyne is completely mistaken in his assessment of the importance of the theory of the Origin. Darwin is just not into the God-bashing business. It was not getting rid of God, nor was it moving us on from final causes, teleology. Indeed, in the Origin, Darwin is as much into final causes as Aristotle. Darwin is interested in efficient causes - natural selection-but he is as interested in final causes: Why does it happen? Get the question right. Darwin is hugely important because he completed the Scientific Revolution (Ruse 2017, 2021b). Final causes can be subsumed under the machine metaphor. The world is to be seen mechanistically as well as from a reductionist perspective. We do not need to invoke a Designer as with Plato. We do not need to get into neo-Aristotelian vital forces like the élan vital. The teleology is indeed heuristic. Those funny plates along the back of the stegosaurus have given rise to a cottage industry of would-be explanations. (Generally accepted today is that they were for heat control of the cold-blooded animalcatching the sun's rays in the morning, and then acting as cooling fins in the heat of the day). But the teleology is more than heuristic. Organisms really are design-like. It is not a weakness that we see this or want to do the impossible and explain it. As with all genuinely mechanical scientific theories, Darwin's theory allows for relative value-the diesel engine is more efficient than the gas engine- but there is no absolute value. That has been drained from our understanding of the world. All we have are laws in motion.

\section{Evolution and Christianity}

Now, with that historical lesson under our belts, let us get back to my guiding question. What is the relationship of evolution to Christianity? Can we-can I-break from the rather conventional analysis I gave in Can a Darwinian be a Christian? Trying to answer this, in 
the light of the history just given, I found myself sailing into waters I never anticipated I would ever enter. What the history showed me was that, with all the talk about progress, there is a massive issue that evolution raises for the Christian, one that had escaped me entirely. It is surely an essential part of the Christian faith that, not only must humans exist, they must be at the top.

4. What is mankind that you are mindful of them, human beings that you care for them?

5. You have made them a little lower than the angels and crowned them with glory and honor.

6. You made them rulers over the works of your hands; you put everything under their feet

(Psalm 8)

Now, how does evolution deal with this? In principle, organicism has no problem at all with this question. There is progress, and humans are at the top. Just what the doctor ordered for the worried Christian. It should come as no surprise that there are some who positively wallow in this. As there will be no surprise that more conventional Christians often rather wished they had not lingered so long in the bath! The Bergsoninfluenced, French Jesuit, and paleontologist Pierre Teilhard de Chardin (1955) splashed happily in the waters and, as a result, he was long controversial, both within and without the Catholic Church. More recently, however, both the last pope and the present pope wrote appreciatively of Teilhard's thinking, and in this revisionist spirit, let us praise him for offering the most systematic and audacious attempt at integration-evolutionary theory and the Christian religion.

The basic thesis of The Phenomenon of Man, written in the 1930s but published posthumously only in 1955, is quite simple. The world and life within it are a process of evolution, of ever-greater complexity, from the inorganic through the simplest organisms, up through various stages of existence to the highest, the "noösphere," the domain of humankind, culminating in something Teilhard called the "Omega Point."

Our picture is of mankind labouring under the impulsion of an obscure instinct, so as to break out through its narrow point of emergence and submerge the earth; of thought becoming number so as to conquer all habitable space, taking precedence over all other forms of life; of mind, in other words, deploying and convoluting the layers of the noosphere. (Teilhard de Chardin 1955, p. 190)

Inventively, if very controversially, Teilhard identified the climax, the Omega Point, with God as incarnated in Jesus Christ.

The universe fulfilling itself in a synthesis of centres in perfect conformity with the laws of union. God, the Centre of centres. In that final vision the Christian dogma culminates. And so exactly, so perfectly does this coincide with the Omega Point that doubtless I should never have ventured to envisage the latter or formulate the hypothesis rationally if, in my consciousness as a believer, I had not found not only its speculative model but also its living reality. (Teilhard de Chardin 1955, p. 293)

The Phenomenon of Man, written by a Christian, does not linger over Heidegger's fundamental question: "Why is there something rather than nothing?" The answer is a given. God did it. Teilhard excuses himself of even thinking much about this question because it is more a matter for physics than his own field of biology. It is all a bit complex for the nonexpert: "As I am a naturalist rather than a physicist, obviously I shall avoid dealing at length with or placing undue reliance upon these complicated and fragile edifices" ( Teilhard de Chardin 1955, p. 38).

Values do interest Teilhard. In the manner of an organicist, he sees ever-greater value the closer we get to humankind, and, the more humankind grows in complexity, the more value we have and the more value we want to generate: "This effort at multiplication and organic expansion is, for him who can see, the summing up and final expression of human 
pre-history and history, from the earliest beginnings down to the present day" (Teilhard de Chardin 1955, p. 190). Panpsychism is the natural philosophy of consciousness for one who thinks in this mode: "We are logically forced to assume the existence in rudimentary form (in a microscopic, i.e. an infinitely diffuse, state) of some sort of psyche in every corpuscle, even in those (the mega-molecules and below) whose complexity is of such a low or modest order as to render it (the psyche) imperceptible-just as the physicist assumes and can calculate those changes of mass (utterly imperceptible to direct observation) occasioned by slow movement" (Teilhard de Chardin 1955, p. 301).

And so, the purpose and the end give the full (and only) meaning to Teilhard's world system. With the noösphere, we go hand in hand with the secular organicist. Then, with the Omega point, we go beyond, putting all in a Christian context: "The end of the world: the overthrow of equilibrium, detaching the mind, fulfilled at last, from its material matrix, so that it will henceforth rest with all its weight on God-Omega" (Teilhard de Chardin 1955, p. 287). All in all, a wonderful world vision.

\section{Alfred North Whitehead}

Controversy notwithstanding, Teilhard is quite conservative. That is why I feel able to talk about "integration." His God is very recognizable as the traditional Christian God. It is the total unacceptability of this kind of God that is the raison d'être for Whitehead's approach to the God problem, developed as it was into so-called "Process Theology" (Cobb and Griffin 1976). Whitehead and his followers wanted nothing to do with the concept of a God who feels no compassion for the family when they learn that their child has leukemia. Nothing to do with the idea of a God who is unmoved-could not be moved because He is eternal and unchanging-by the death of Anne Frank in Bergen-Belsen. Anselm writes, "For when thou beholdest us in our wretchedness, we experience the effect of compassion, but thou dost not experience the feeling" (Anselm 1903, p. 13). Meanwhile, Aquinas writes, "To sorrow, therefore, over the misery of others does not belong to God" (Aquinas 1952, Volume I, Book 21, Section 3). In any case, as an out-and-out follower of Schelling, on the one hand Whitehead took the inherent change of organicism as all-important, and, on the other hand, was totally committed to a God in the world rather than a God who is in some sense logically separate. Whitehead writes:

The vicious separation of the flux from the permanence leads to the concept of an entirely static God, with eminent reality, in relation to an entirely fluent world, with deficient reality. But if the opposites, static and fluent, have once been so explained as separately to characterize diverse actualities, the interplay between the thing which is static and the things which are fluent involves contradiction at every step in its explanation. (Whitehead [1929] 1978, p. 346)

That means that God Himself must be part of the evolutionary process. Not the world itself-pantheism - but in all parts of the world — what Whitehead, after Schelling, called "panentheism." And since the process of evolution involves struggle-the Englishman Whitehead is part of the Malthusian culture that produced Darwin, rather than the culture of the Frenchman Teilhard - this means that God too must be suffering and striving: "He suffers from the suffering Inherent to the transitory." He has-as the story of Jesus shows full well-emptied Himself of His powers and works alongside us: "He made himself nothing by taking the very nature of a servant, being made in human likeness" (Philippians 2:7). Kenosis.

What about some of the questions that worry Christians? First, origins. I do want to stress that I do not think that Teilhard simply embraced every aspect of the traditional picture of God-obviously he did not-but, as we have seen, God as creator from nothing does seem to be part of his theological world picture. Ian Barbour, drawn to process theology, writes: "Teilhard says that God is "self-sufficing" and initially "stood alone." He denies the need for a "pre-existing substratum" on which God operated and holds that matter is not eternal" (Barbour 1969, p. 50). Whitehead, as Barbour notes, is more radical: "Whitehead shares Teilhard's themes of continuing creation and unification, but 
he explicitly rejects "creation out of nothing"'" (Barbour 1969, p. 51). He holds that time is infinite. There was no first day, no initial act of origination, but only a continuing bringinginto-being in which past, present, and future are structurally similar. God has a priority in ontological status but no temporal priority over the world. God "is not before all creation but with all creation." (Barbour 1969, p. 51). Elsewhere, "God is in the world or nowhere, creating continuously in us and around us. The creative principle in animate and so-called inanimate matter, in the ether, water, earth, [and] human heart" (Price 1954, p. 370).

As for Teilhard, for Whitehead ethical dicta emerge naturally from his system. We are cocreators with God. He is good, and it is for us to emulate and aid Him in His tasks. Since everything is part of the whole creative system, interrelated in a whole, our obligations stem naturally from this. Leading process theologian John Cobb writes, "a human life is 'of more value than many sparrows' (Matthew 10:31) does not warrant the conclusion that sparrows are worth nothing at all. Indeed, it presupposes the opposite. The Heavenly Father cares even for sparrows; how much more for human beings! This certainly means that people too should be concerned more about a human being than a sparrow. Much more! But it does not warrant the teaching that sparrows exist only as a means to human ends ... God is pictured as loving the creatures and caring for them, not only human beings, but sparrows as well" (Cobb 1991, p. 44). Mischievously, I do ask sometimes if Whiteheadians can be other than vegans (a good topic for Star Island, as my Christian friends, often very keen Whiteheadians, wade into their butter-smothered, New England lobsters).

I have stressed that, although many have taken Teilhard as heretically throwing away the very essence of Christian doctrine, in major respects, he is very orthodox. His aim was to see how conventional Christianity can be rethought in the light of evolution. As, of course, was precisely the intent of Whitehead who, unconstrained by a Jesuit education, felt free to break with this kind of thinking entirely. We are cocreating with God, and that means there can be no absolute guarantee of success.

Maybe he wakes periodically at night,

Wiping away the tears he doesn't know

He has cried in his sleep, not having had time yet to tell

Himself precisely how it is he must mourn, not having had time yet

To elicit from his creation its invention

Of his own solace. (Rogers 2001, pp. 182-83)

Process pastor and theologian Bruce G. Epperly (2011) grasps the nettle, as one might say in an appropriate metaphor. We humans could let off atom bombs, Dr. Strangelove style, and end it all. Not to worry! "If humans choose the pathway of self-destruction, God will nurture other streams of evolution on earth and other planets" (Epperly 2011, p. 99). We have only ourselves to blame. And whether there is life after death, to make up for it all, is not a done deal. "At present it is generally held that a purely spiritual being is necessarily immortal. The doctrine here developed gives no warrant for such belief. It is entirely neutral on the question of immortality" (Epperly 2011, pp. 136-37, quoting Whitehead 1960, p. 107).

\section{Darwinism and Humankind}

What then of those who opt for mechanism? Straight away, as Christians, we run into problems with Darwinism. It is not that Darwin's theory cannot explain the evolution of humans. That has never been an issue. From the first, Darwin was convinced that his theory applies to humans, including their intelligence-both as reasoning beings and as moral beings (Darwin 1871; Ruse 2012). The question is about the necessity and high status of humans. Did humans have to evolve? What does Darwin's theory tell us about the status of humans? Is the whole evolutionary process directed toward us? We have final causes with respect to individuals. Do we have final causes with respect to species? Specifically, is evolution caused by natural selection progressive, with human beings as the apotheosis? 
Deep down inside himself, Darwin knew that his theory spelt a really radical break. It was not that it failed to offer an explanation of phylogenetic final cause-progress-but that it denied that there could be such an explanation. In the world of machines, if you so wish, you may judge something better or superior. It is just that you are not going to find nature telling you this. Progress means absolute value in some sense, and as noted already the world of machines, mechanism simply does not allow absolute value judgments (Ruse 2021a). The world of the diesel engine may be better than the world of the petrol (gasoline) engine-better mileage, less need of upkeep, and so forth. In a world of global warming, it is far from obvious that this judgment holds. It is not that judgments cannot be made or that judgments should not be made, but that the judgments are for us to make. Nature may give us pertinent information, but it gives no absolute judgments.

Reflecting the magnitude of the move he was making —implying at least —we find that Darwin was never quite sure how you define the "top." "It is absurd to talk of one animal being higher than another. -We consider those, when the intellectual faculties [/] cerebral structure most developed, as highest. - A bee doubtless would when the instincts were -" (Darwin 1987, Notebook B, p. 74), writes Darwin. It really didn't seem that humans had an exclusive lien on the summit: "People often talk of the wonderful event of intellectual man appearing. - the appearance of insects with other senses is more wonderful; its mind more different probably, \& introduction of man nothing compared to the first thinking being, although hard to draw line. - " (Notebook B, p. 207). Darwin was always opposed to Germanic-type evolutionary progressions-organicist progress-based on the way that the embryo develops systematically from within, to the full adult, without the aid of outside forces. This was not Darwin's picture of things. "I grant there will generally be a tendency to advance in complexity of organisation," however, "the theory of natural selection ... implies no necessary tendency to progression" (Notebook E, pp. 95-96), writes Darwin. Darwin felt this way before discovering selection and even more as his thinking matured after the discovery. Necessity of this kind is simply alien to-denied by-evolution through selection.

This non-progressionist view of Darwin's theory continues down to the present, "neo-Darwinian" view of the theory, one that blends Darwinian selection with Mendelian genetics, today known as molecular genetics (Ruse 2006). Darwin's prediction that the causes of new variation, mutation, would be found and prove not to have any inbuilt direction, proved correct. The variations are caused by mistakes in copying and like factors. Stephen Jay Gould was (characteristically) rhetorically flamboyant on the topic. In the 1980s, he declared that biological progress was "a noxious, culturally embedded, untestable, nonoperational, intractable idea that must be replaced if we wish to understand the patterns of history" (Gould 1988, p. 319). Gould saw no inevitability to the emergence of humans. Making a facetious reference to the asteroid that hit the Earth 65 million years ago, thereby wiping out the dinosaurs and making possible the flowering of the hitherto rat-like, nocturnal mammals, he wrote: "Since dinosaurs were not moving toward markedly larger brains, and since such a prospect may lie outside the capabilities of reptilian design ... , we must assume that consciousness would not have evolved on our planet if a cosmic catastrophe had not claimed the dinosaurs as victims. In an entirely literal sense, we owe our existence, as large and reasoning mammals, to our lucky stars" (Gould 1988, p. 318).

None of this is to deny that there have been attempts to extract progress to humans out of natural selection theory. Darwin believed in social progress and he found it nigh impossible to keep it out of his science. At the end of the Origin, letting his hair down, Darwin wrote:

[F]rom the war of nature, from famine and death, the most exalted object which we are capable of conceiving, namely, the production of the higher animals, directly follows. There is grandeur in this view of life, with its several powers, having been originally breathed into a few forms or into one; and that, whilst this planet has gone cycling on according to the fixed law of gravity, from so simple a 
beginning endless forms most beautiful and most wonderful have been, and are being, evolved. (Darwin 1859, pp. 489-90)

How could this be possible? For the organicist, the cause of directive change comes from internal factors. For the Darwinian mechanist, the cause of directive change must come from external factors, namely natural selection. Richard Dawkins is the Darwinians' Darwinian (Dawkins 1983). Nevertheless, he is an ardent progressionist: "Directionalist common sense surely wins on the very long, time scale: once there was only blue-green slime and now there are sharp-eyed metazoa" (Dawkins and R 1979, p. 508). It is soon very clear that the sharpest eyed of the metazoa are human beings. Why? Arms races. Dawkins brings up the increasing employment by competing nations of evermore sophisticated computer technology. In the animal world, Dawkins sees the evolution of bigger and bigger brains. We won! Dawkins refers to a notion known as an animal's EQ, standing for "encephalization quotient" (Jerison 1973). This notion is a kind of cross-species measure of IQ, factoring out the amount of brain power needed simply to get an organism to functionwhales require much bigger brains than shrews because they need more computing power to get their bigger bodies to function. With the surplus left over, one can then scale raw intelligence. Dawkins (1986) writes, "The fact that humans have an EQ of 7 and hippos an EQ of 0.3 may not literally mean that humans are 23 times as clever as hippos! But the EQ as measured is probably telling us something about how much 'computing power' an animal probably has in its head, over and above the irreducible amount of computing power needed for the routine running of its large or small body" (p. 189). Even an organism with a low EQ probably does not need much help in making out the precise nature and import of that something.

We know already that this argument cannot work. It is like squaring the circle. Progress to humans is absolute value. Mechanism forswears absolute value. The fact is that sometimes big brains are not the best solution. Apart from anything else, they are very expensive to maintain. Gould's student, paleobiologist Jack Sepkoski, makes the point in stark, if somewhat vulgar, terms: "I see intelligence as just one of a variety of adaptations among tetrapods for survival. Running fast in a herd while being as dumb as shit, I think, is a very good adaptation for survival" (Ruse 1996, p. 486). So much for "four legs good, two legs better." Darwinism does not give top status to humans. Saying humans are the most valuable organisms is an absolute value claim, and mechanistic science simply cannot yield these claims. It is open to us to make such a judgment, but that is another thing (Ruse 2021a). We are not going to get it from the science. Is the science against us making such a judgment? I do not think so, but if it meant downgrading other organisms, it would caution us to be wary about making too strong a judgment. From the viewpoint of Darwinism, other organisms are no less in all of this than are humans. Indeed, while humans are obviously now a very successful species, one would hardly want to say — given that we are in the middle of a pandemic - that no other species is as successful, if not more successful. Again, these are our value judgments to make but we should not pretend that we are extracting them from the science.

\section{Evolution and Christianity}

I said that I felt the move to history moved the discussion forward. I must now make good on this claim. When I lost my faith, I was never a strident atheist, and in any case, I soon settled into a kind of agnosticism. I think it would be true to say that, at least until the Arkansas trial and probably later, my agnosticism was basically a place holder between belief and nonbelief. I do not know the identity of Jack the Ripper. I do not know if God exists. I cannot give answers, so I do not waste time on them. Move on. In his The Language of God, Francis Collins refers to agnosticism as a "cop out." I do not think this was ever quite true for me, but I know what he means. For me, it was not so much that I did not have the guts to make a decision-to declare myself an atheist, if that was really where I was at-it was more that the God question did not really grab my emotions. Whatever my exact position, the God-science issue was more an intellectual enterprise than a matter of pressing 
personal concern. In a way, I think this was my dominant perspective when writing Can $a$ Darwinian be a Christian? But not entirely. As I said earlier, writing the book made me realize that I was shaping my agnosticism. It was no longer blank-slate agnosticism. Thanks to evolution, it had no place for Augustinian Christianity. I was beginning to see that there is something dynamic about the relationship between Christianity and Darwinism. You can continue being a Christian after Darwinism, but as I dug into history and brought the organicism/mechanism divide to the front, it became increasingly clear that things after Darwin could never be the same. The Christianity I had rejected when I was 20 was no longer the Christianity I was starting to uncover. I am incredibly impressed by both Teilhard and Process Theology, and they have been moving me forward and shaping my agnosticism. They do not convert me, but Process Theology in particular convinces me that the Christianity I cannot accept is a great deal more dynamic than I thought. A God without compassion is not only biblically suspect-did not Jesus weep at the tomb of Lazarus (John 11:38), did not Jesus show great compassion when the Centurion came to him (Matthew 8:5-13)? It is theologically horrible on a par with blood sacrifices to save my soul. And then, going back to Darwin and realizing that he gives no hard answers: The solutions must come from within. Elsewhere, I have spoken of myself as a Darwinian existentialist, meaning Darwin points us to the exhilarating but rather fearful realization that we are condemned to freedom. We must choose, and if we do not choose, that in itself is a choice (Ruse 2019, 2021a).

In a way, I am starting to feel that I have come full circle in respects back to the Quakerism of my childhood. Quakers have always been drawn to apophatic theology. We cannot say what God is, but we can say what God is not. This, as it is for Quakers, is often linked with mysticism, again the belief that much is simply beyond our kin. I find deeply insightful the saying of the geneticist J. B. S. Haldane (1927) that the world is not only queerer than we think it is, it is queerer than we could think it is. Combine this with Richard Dawkins' (2003) all-too-true comment, that adaptations that fitted us to get out of the jungle and onto the plains are hardly to be expected to yield the secrets of the universe. I am still, after more than 50 years as a professional philosopher, amazed by our total inability to crack the mind-body problem. We can say a lot about the brain and the mind, for instance, which parts of the brain are used for language function. But why a bunch of molecules should think, and have consciousness, is a mystery. And things only get worse. Quantum entanglement tells us that information can be transferred immediately across vast distances in the universe. Anyone who does not find that to be absolutely mind-blowing - to use a phrase-does not deserve to be a philosopher.

My Darwinian perspective fits with all of this. The empirical world is not going to yield the fundamental answers. Ultimate origins, ultimate purposes, nature of thought, God. This is not a failure by science. If you think metaphorically, as I have argued we do, then as Kuhn pointed out, you would rather put on blinkers, ruling some questions as unanswerable by the science (Ruse 2010). If the world is a machine, then you cannot answer questions about ultimate origins - why is there something rather than nothing? Like the cookbook says: First, take your hare. Accept that the world exists. Likewise, questions about ultimate purposes are ruled out. All you can talk about are things in motion. This does not mean there are no answers or that you cannot strive to find them. You just cannot get them from the empirical world. If answers are to be given at all, they must come from within, even if you believe that Someone Up There is skyping the answers to you-sensus divinitatis. At the same time, my position welcomes attempts by the likes of Teilhard and Whitehead to come, in a nontrivial way, to the challenges Darwin does give to Christianity. Theologically, I am a Kierkegaardian (Davies and Ruse 2021). I have little time for natural theology. I agree with John Henry Newman (1973, p. 97) that the correct position for the believer is: "I believe in design because I believe in God, not I believe in God because I believe in design." All the talk about "fine tuning" (Barrow and Tipler 1986) leaves me cold. Think of a number, double it, and the answer you want is a half. Apart from anything else, the physicist Steven Weinberg (1999) argues that the world is nothing like as fine-tuned 
as people often claim it is. In a debate with the physicist/theologian John Polkinghorne, he said:

[I] am not terribly impressed by the examples of fine-tuning of constants of nature that have been presented. To be a little bit more precise about the case of carbon, the energy levels of carbon, which is the most notorious example that's always cited, there is an energy level that is $7.65 \mathrm{MeV}$ above the ground state of carbon. If it was .06 of an $\mathrm{MeV}$ higher, then carbon production would be greatly diminished and there would be much less chance of life forming. That looks like a $1 \%$ finetuning of the constants of nature ... However, as has been realized subsequently after this 'fine-tuning' was pointed out, you should really measure the energy level not above the ground state of carbon but above the state of the nucleus Beryllium $8\left({ }^{8} \mathrm{Be}\right)$ plus a helium nucleus ... In other words, the fine-tuning is not $1 \%$ but it's something like $25 \%$. So, it's not very impressive fine-tuning at all. (Available online: http://skepticwiki.org/index.php/Triple_Alpha_Process accessed on 1 December 2020)

I am with Newman here. It seems so shabby, if belief in God depends on cosmic coincidences or not. The God who is worth worshiping is He who thrusts Himself at me. Christianity is faith or nothing. A leap into the absurd.

When someone is to leap he must certainly do it alone and also be alone in properly understanding that it is an impossibility. ... the leap is the decision.... . But if a resolution is required, presuppositionlessness is abandoned. The beginning can occur only when reflection is stopped, and reflection can be stopped only by something else, and this something else is something altogether different from the logical, since it is a resolution. (Kierkegaard 1992, pp. 102,113)

And:

Faith is the objective uncertainty with the repulsion of the absurd, held fast in the passion of inwardness, which is the relation of inwardness intensified to its highest. This formula fits only the one who has faith, no one else, not even a lover, or an enthusiast, or a thinker, but solely and only the one who has faith, who relates himself to the absolute paradox. (pp. 610-611)

I have not faith. You might say that this is my fault. I am not making enough effort. Mischievously (at least I hope it is mischievous and not meant seriously), you might say that this only goes to show that Calvin is right, that I am so tainted with original sin I cannot tell when God is reaching out to me. It is rather that I cannot accept the Christians' answers. Although I was brought up on the Screwtape Letters, C. S. Lewis is no great favorite of mine. I cannot stand the Narnia series. Far better the Swallows and Amazons series, by Arthur Ransome, about middle-class kids on holiday in the Lake District in the 1930s. No magic wardrobes, just sailing boats. But I resonate when Lewis talks of his conversion to Christianity:

You must picture me alone in that room in Magdalen [College, Oxford], night after night, feeling, whenever my mind lifted even for a second from my work, the steady, unrelenting approach of Him whom I so earnestly desired not to meet. That which I greatly feared had at last come upon me. In the Trinity Term of 1929 I gave in, and admitted that God was God, and knelt and prayed: perhaps, that night, the most dejected and reluctant convert in all England. (Lewis 1955, p. 115)

That hits the nail on the head. Until my 20s, I believed in God because I wanted to believe in God. It made me feel secure and comfortable about the past. I had a friend to whom I could turn, although I confess most of the turning was to ask him for things. Then I sensed, and now I see, that faith is not for me to choose or not. I can reject it or not, but having faith means having true beliefs and these cannot come from me. They must be given. So, no beliefs for me, not even of the Teilhardian or Whiteheadian kind. At the same time, I do not ignore these beliefs. If there is a God, I would be very surprised if He is not part of the ongoing creative process. What I am saying is that for me, as an agnostic 
rather than an atheist, I am open-I must be open-to be convinced that there is something (true) to the Christian position. But not any old Christian tradition. It has to be one that recognizes the fundamental shift that evolution-Darwinism-demands. If there is a God, I am sure He is going to be involved in the Creation, if not precisely as Process Theology suggests, at least in that ballpark.

Again, as a Darwinian, if there be a God, we are still going to have to make the commitments and-if heaven there be-in order to get there, not do simply what we are told. If there be a God, it is still I who must commit myself to the Inner Light and let it rule my life. I must reach out to all my students, the difficult and unattractive as well as the easy and attractive. It is my choice whether I accept (the secularized form of) the Inner Light. But that it is binding on me, even if it is a function of my psychology, is not my decision. It is not I who decides I am doing wrong when, on a Friday afternoon, I slip out by the back entrance to join my pals in the faculty club, thus avoiding a tearful student at the front entrance worried about their mark. Hence, I do feel strongly that my IRAS friends and I are fellow travelers in our quest for understanding. We take seriously the issues that we should take seriously. Life is fun but it is not for the lazy or the indifferent. That is why I cherish my annual week with Christians on Star Island. To be honest, I am not sure that I believe more or less than some of my friends there. It is just that, on Sunday mornings, they like going to Church and singing hymns and gossiping about absent members over coffee afterward, whereas I like making waffles to go with maple syrup-my wife is Canadian-and reading the New York Times.

That is why I speak of a journey not a destination. If you ask me "What do I believe exactly?", then I cannot answer you. I am an apophatic philosopher! If you ask me, "Do I feel my life's quest, and those of fellow travelers-very much including believers-has brought me closer to deep insights about our existential fate?", then I respond cheerfully and positively. I may never reach my destination. But, oh what a joy and a privilege to take the journey to where I find myself today. What a joy and a privilege to take the journey with fellow seekers.

Funding: This work received no external funding.

Data Availability Statement: No empirical data, not applicable.

Conflicts of Interest: The author declares no conflict of interest.

\section{References}

Anselm, Saint. 1903. Anselm: Proslogium, Monologium, An Appendix on Behalf of the Fool by Gaunilon; and Cur Deus Homo. Translated by S. N. Deane. Chicago: Open Court.

Aquinas, Saint T. 1952. Summa Theologica, I. London: Burns, Oates and Washbourne.

Barbour, Ian. G. 1969. Teilhard's Process Metaphysics. The Journal of Religion 49: 136-59. [CrossRef]

Barnes, Jonathan, ed. 1984. The Complete Works of Aristotle. Princeton: Princeton University Press.

Barrow, John D., and Frank J. Tipler. 1986. The Anthropic Cosmological Principle. Oxford: Clarendon Press.

Bergson, Henri. 1907. L'évolution créatrice. Paris: Alcan.

Bergson, Henri. 1911. Creative Evolution. New York: Holt.

Boyle, Robert. 1688. A Disquisition about the Final Causes of Natural Things: Wherein it is Inquir'd Whether, And (if at all) With what Cautions, a Naturalist should admit Them? London: John Taylor.

Cobb, John. B. 1991. Matters of Life and Death. Louisville: Westminster.

Cobb, John. B., and David Ray Griffin. 1976. Process Theology: An Introductory Exposition. Philadelphia: Westminster Press.

Cooper, John M., ed. 1997. Plato: Complete Works. Indianapolis: Hackett.

Coyne, Jerry. 2012. The Odd Couple: Why Science and Religion Shouldn't Cohabit. Available online: Https:/ /Www.Youtube.Com/ Watch?v=0wCIa_OQ-2s\&Noredirect=1. (accessed on 1 December 2020).

Darwin, Charles. 1851a. A Monograph of the Fossil Lepadidae; or, Pedunculated Cirripedes of Great Britain. London: Palaeontographical Society.

Darwin, Charles. 1851b. A Monograph of the Sub-Class Cirripedia, with Figures of all the Species. The Lepadidae; or Pedunculated Cirripedes. London: Ray Society.

Darwin, Charles. 1854a. A Monograph of the Fossil Balanidae and Verrucidae of Great Britain. London: Palaeontographical Society.

Darwin, Charles. 1854b. A Monograph of the Sub-Class Cirripedia, with Figures of all the Species. The Balanidge (or Sessile Cirripedes); the Verrucidae, and C. London: Ray Society. 
Darwin, Charles. 1859. On the Origin of Species by Means of Natural Selection, or the Preservation of Favoured Races in the Struggle for Life. London: John Murray.

Darwin, Charles. 1871. The Descent of Man, and Selection in Relation to Sex. London: John Murray.

Darwin, Charles. 1987. Charles Darwin's Notebooks, 1836-1844. Edited by Paul H. Barrett, Peter J. Gautrey, Sandra Herbert, David Kohn and Sydney Smith. Ithaca: Cornell University Press.

Davies, Brian, and Michael Ruse. 2021. Taking God Seriously: Two Different Voices. Cambridge: Cambridge University Press.

Dawkins, Richard. 1983. Universal Darwinism. In Evolution from Molecules to Men. Edited by Derek S. Bendall. Cambridge: Cambridge University Press, pp. 403-25.

Dawkins, Richard. 1986. The Blind Watchmaker. New York: Norton.

Dawkins, Richard. 2003. A Devil's Chaplain: Reflections on Hope, Lies, Science and Love. Boston and New York: Houghton Mifflin.

Dawkins, Richard, and Krebs John R. 1979. Arms races between and within species. Proceedings of the Royal Society of London, B 205: 489-511.

Dijksterhuis, Eduard Jan. 1961. The Mechanization of the World Picture. Oxford: Oxford University Press.

Epperly, Bruce G. 2011. Process Theology: A Guide for the Perplexed. London: T\&T Clark.

Gould, Stephen Jay. 1988. On replacing the idea of progress with an operational notion of directionality. In Evolutionary Progress. Edited by Matthew H. Nitecki. Chicago: The University of Chicago Press, pp. 319-38.

Haeckel, Ernst. 1896. The Evolution of Man. New York: Appleton.

Haldane, J. B. S. 1927. Possible Worlds and Other Essays. London: Chatto and Windus.

Jerison, Harry. 1973. Evsolution of the Brain and Intelligence. New York: Academic Press.

Kant, Iimmanuel. 1928. The Critique of Teleological Judgement. Translated by James C. Meredith. Oxford: Oxford University Press. First published 1790 .

Kierkegaard, Søren. 1992. Concluding Unscientific Postscript to Philosophical Fragments, Volume 1 (Kierkegaard's Writings, Vol 12.1). Translated by Howard V. Hong, and Edna H. Hong. Princeton: Princeton University Press.

Kuhn, Thomas. 1962. The Structure of Scientific Revolutions. Chicago: University of Chicago Press.

Kuhn, Thomas. 1993. Metaphor in science. In Metaphor and Thought, 2nd ed. Edited by Andrew Ortony. Cambridge: Cambridge University Press, pp. 533-42.

Lewis, C. S. 1955. Surprised by Joy: The Shape of My Early Life. London: Geoffrey Bles.

Moore, Aubrey. 1890. The Christian doctrine of God. In Lux Mundi. Edited by Charles Gore. London: John Murray, pp. 57-109.

Morris, Henry M. 2020. The Scientific Case against Evolution. Institute for Creation Science. Available online: https: / www.icr.org/ home/resources/resources_tracts_scientificcaseagainstevolution/ (accessed on 1 December 2020).

Newman, John Henry. 1973. The Letters and Diaries of John Henry Newman, XXV. Edited by Charles Stephen Dessain and Thomas Gornall. Oxford: Clarendon Press.

Pepper, Stephen C. 1942. World Hypotheses: A Study in Evidence. Berkeley: University of California Press.

Price, Lucien. 1954. Dialogues of Whitehead. Boston: Little, Brown.

Richards, Robert J. 2003. The Romantic Conception of Life: Science and Philosophy in the Age of Goethe. Chicago: University of Chicago Press.

Rogers, Patti. 2001. Song of the World Becoming: New and Collected Poems 1981-2001. Minneapolis: Milkweed.

Ruse, Michael. 1979. The Darwinian Revolution: Science Red in Tooth and Claw. Chicago: University of Chicago Press.

Ruse, Michael. 1988. But is it Science? The Philosophical Question in the Evolution/Creation Controversy. Buffalo: Prometheus.

Ruse, Michael. 1996. Monad to Man: The Concept of Progress in Evolutionary Biology. Cambridge: Harvard University Press.

Ruse, Michael. 2001. Can a Darwinian be a Christian? The Relationship between Science and Rreligion. Cambridge: Cambridge University Press.

Ruse, Michael. 2006. Darwinism and its Discontents. Cambridge: Cambridge University Press.

Ruse, Michael. 2010. Science and Spirituality: Making Room for Faith in the Age of Science. Cambridge: Cambridge University Press.

Ruse, Michael. 2012. The Philosophy of Human Evolution. Cambridge: Cambridge University Press.

Ruse, Michael. 2017. On Purpose. Princeton: Princeton University Press.

Ruse, Michael. 2019. A Meaning to Life. Oxford: Oxford University Press.

Ruse, Michael. 2021a. A Philosopher Looks at Human Beings. Cambridge: Cambridge University Press.

Ruse, Michael. 2021b. The Scientific Revolution. In The Cambridge History of Atheism. Edited by Stephen Bullivant and Michael Ruse. Cambridge: Cambridge University Press.

Schelling, Friedrich Wilhelm Joseph. 1988. Ideas for a Philosophy of Nature. Cambridge: Cambridge University Press. First published 1797.

Spencer, Herbert. 1868. The development hypothesis. In Essays: Scientific, Political and Speculative. London: Williams and Norgate, pp. 377-83. First published 1852.

Teilhard de Chardin, Pierre. 1955. Le Phénomène Humain. Paris: Editions de Seuil.

Weinberg, Steven. 1999. A designer universe? New York Review of Books 46: 46-48.

Whitehead, Alfred North. 1978. Process and Reality: An Essay in Cosmology. New York: Free Press. First published 1929.

Whitehead, Alfred North. 1926. Science and the Modern World. Cambridge: Cambridge University Press.

Whitehead, Alfred North. 1960. Religion in the Making. New York: Meridian. 